\title{
University experience of a tutorial action programme during the COVID-19 lockdown in teacher training at a Valencian University (Spain)
}

Experiencia universitaria de un programa de acción tutorial durante el periodo de confinamiento ocasionado por la pandemia (COVID-19) en la formación docente en una Universidad Valenciana (España)

\section{Volumen 21, Número 2 \\ Mayo - Agosto \\ pp. 1-28}

\author{
Vladimir E. Martínez-Bello \\ José Díaz-Barahona \\ María del Mar Bernabé-Villodre
}

\section{Citar este documento según modelo APA}

Martínez-Bello, Vladimir E., Díaz-Barahona, José., y Bernabé-Villodre, María del Mar. (2021). University experience of a tutorial action programme during the COVID-19 lockdown in teacher training at a Valencian University (Spain). Revista Actualidades Investigativas en Educación, 21(2), 1-28. Doi. 10.15517/aie.v21i2.46793 


\title{
University experience of a tutorial action programme during the COVID- 19 lockdown in teacher training at a Valencian University (Spain)
}

Experiencia universitaria de un programa de acción tutorial durante el periodo de confinamiento ocasionado por la pandemia (COVID-19) en la formación docente en una Universidad Valenciana (España)

\author{
Vladimir E. Martínez-Bello ${ }^{1}$ \\ José Díaz-Barahona² \\ María del Mar Bernabé-Villodre 3
}

\begin{abstract}
Coronavirus disease 2019 (COVID-19) is perceived as the worst modern-times pandemic. This entirely new health situation entailed a new challenge to the education system. To our knowledge, the impact of alternative teaching methods derived from the social distancing imposed by COVID-19 on university student perception in teacher education has not been investigated. The aim of this study was to analyse an educative experience developed in a Faculty of Teaching from March 2020 to July 2020 in order to overcome the challenge imposed by COVID-19. A qualitative approach was used for data collection and analysis using four information sources: (a) The final written documents developed by the working groups (b) The online oral presentation of their work (c) The semistructured interviews conducted through videoconferencing during the lockdown and, (d) The focus groups meetings. We have identified 8 major categories. Our results show that: (a) students find videoconferences are a tool that offsets the issues of social distancing; (b) intrinsic motivation is essential to overcome the perceived barriers; (c) the move to a virtual environment allowed students to deepen their methodological skills; (d) students now see themselves more competent regarding academic information research; e) the constant interaction among group members and the teacher is a key element to achieve a positive experience during social isolation; (f) new logistic and operational dynamics for cooperative working were constructed as a result of using videoconferences. We highlighted the barriers and facilitators perceived by students during the implementation of a tutorial action during the COVID-19 pandemic.
\end{abstract}

Keywords: pandemics, higher education, teacher education, teleconferencing.

Resumen: La enfermedad del Coronavirus 2019 (COVID-19) se percibe como la peor pandemia de los tiempos modernos. Hasta donde sabemos, el impacto de los métodos de enseñanza alternativos derivados del distanciamiento social impuesto por COVID-19 en la percepción del estudiantado universitario no ha sido investigado. El objetivo principal de este estudio fue analizar una experiencia educativa desarrollada en una Facultad de Educación entre los meses de marzo y julio de 2020 para superar el reto impuesto por COVID-19. Hemos utilizado cuatro fuentes de información para analizar el impacto de un programa de acción tutorial virtual para desarrollar un anteproyecto de investigación: a) Documentos escritos b) La presentación oral de sus trabajos c) Las entrevistas semiestructuradas realizadas por videoconferencia y, d) Los grupos de discusión. Nuestros resultados muestran que: a) el estudiantado considera que las videoconferencias son un instrumento que compensa los problemas del distanciamiento social; b) la motivación intrínseca es esencial para superar las barreras percibidas; c) el paso a un entorno virtual permitió al estudiantado profundizar en sus aptitudes metodológicas; d) el estudiantado se percibe ahora más competente en lo que respecta a la investigación; e) la interacción constante entre los miembros del grupo y el profesor es un elemento clave para lograr una experiencia positiva durante el aislamiento social; f) se construyeron nuevas dinámicas para el trabajo cooperativo como resultado del uso de las videoconferencias. En conclusión, destacamos las barreras y los facilitadores percibidos por el estudiantado durante la implementación de una acción tutorial durante la pandemia de COVID-19.

Palabras clave: pandemia, universidad, formación docente, videoconferencias.

\footnotetext{
1 University of Valencia, Valencia, Spain. Dirección electronica: Vladimir.martinez@uv.es Orcid http://orcid.org/0000-0002-3408-9678

2 University of Valencia, Valencia, Spain. Dirección electronica: Jose.diaz-barahona@uv.es Orcid https://orcid.org/0000-0002-9155-5372

${ }^{3}$ University of Valencia, Valencia, Spain. Dirección electronica: Maria.mar.bernabe@uv.es Orcid https://orcid.org/0000-0001-8983-6602
}

Artículo recibido: 18 de noviembre, 2020

Enviado a corrección: 4 de marzo, 2021

Aprobado: 19 de abril, 2021 


\section{Introduction}

\subsection{Impact of COVID-19 in the education system}

Coronavirus disease 2019 (COVID-19) caused by Severe Acute Respiratory Syndrome Coronavirus 2 (SARS-CoV-2), is perceived as the worst modern-times pandemic. In January 2020, the World Health Organization (WHO, 2020) declared a new coronavirus disease outbreak, COVID-19, to be a public health emergency of international concern. To mitigate the spread and infection, governments from around the world suspended traveling, social activities, and gatherings in public spaces. The modification of educational activities was among those measures, entailing a new challenge to the education system. Within this framework, governments in globally suspended in-person teaching both in school and universities. Our country was among the first countries hit by COVID-19. As per executive's orders, classroombased educational activity in the country was suspended in all educational organizations and levels; instead, they were to be maintained through distanced and online alternatives, whenever possible.

This entirely new health situation required university teachers to adapt the objectives, processes, and assessment methods of their subjects to the new pandemic-generated scenario in a short time frame (González-Zamar, Abad-Segura and Bernal-Bravo, 2020). Our University Council faced the challenge of maintaining the quality of university teaching, while taking into account the delicate psychological, social and economic situation of the general population and the student body.

\subsection{Aims}

Therefore, the present study wants to share with the higher education community an educational experience developed with university students in a Faculty of Teaching within the subject of Physical Education for Early Childhood Teacher Education. To our knowledge, the impact of alternative teaching methods derived from the social distancing imposed by COVID19 on student perception has not been investigated through a qualitative approach. Therefore, the main of this study was to analyse an educative experience developed in a Faculty of Teaching in order to overcome the challenge imposed by COVID-19. Furthermore, the manuscript has three specific aims: (1) to describe the process of creating, implementing, and developing a tutorial action program in a curricular course in a Faculty of Teaching under social distancing conditions; (2) to analyse how students perceive the impact of a virtual tutorial action program for developing a preliminary research project with special consideration of the barriers 
and enablers of this new way of working; and (3) to reflect on the importance of distanced tutorial action in the university's role in training new generations of professionals committed to social change.

\section{Theoretical framework}

\subsection{The new challenge of COVID-19 in university education}

Traditional universities have overcome multiple challenges throughout their existence. The lockdown arising from the sanitary state of alarm led public universities to consider new alternatives, becoming a tipping point in the education field and the digitalisation of education (Almazán, 2020; Beltrán et al.,2020). It is not only about the unequal access to technology derived from lack of economic resources or cultural capital (Feito, 2020) but also about the differences in digital training received by teachers, which has led to a gap in student care during the pandemic. Educators have adapted through technology and rethinking teaching practices (Sánchez et al.,2020) to reach the whole of the student body.

Sánchez et al. (2020) signpost to three more issues stemming from this forced digitalisation of university-level teaching: logistic, technologic, and pedagogical. All of them can lead to stress and anxiety (Rogero-García, 2020) for both students and teachers when taking part in the learning process. In this new scenario, as Toquero (2020) suggested, higher education institutions must seize these opportunities to strengthen the data monitoring, documentation, and evidence-based practices of the services offered to the students.

In recent months, the literature on potential action plans as a reaction to COVID-19 has increased considerably especially in the medical education context (Plancher, Shanmugam and Petterson,2020). Chick et al. (2020) have proposed innovative solutions for mitigating the loss of in-person academic and operative education for surgical residents. Nguyen et al. (2020) have discussed the advantages and disadvantages of digital platforms for medical education. Guadix et al. (2020) have identified the concerns of medical students interested in pursuing neurosurgery during the pandemic. However, Zhang, Wang, Yang and Wang (2020) have suggested that one of the most pressing tasks is to conduct in-depth investigations into online education, especially regarding student support. In this regard, Baloran (2020) has assessed the knowledge, attitudes, anxiety, and personal coping strategies of college students during the pandemic in Southern Philippines. In the United States, Gallagher and Schleyer (2020) have conducted a brief, anonymous survey to learn more about how COVID-19 was affecting 
medical students, interns, and residents in internal medicine and emergency medicine, and fellows in pulmonary and critical care at their institutions.

\subsection{Tutorial action as an instrument to increase participation}

\subsubsection{Characteristics of the tutorial action}

Student-centred education, the construction of new pedagogical processes and the role of the university in the society of the 21 st century are fundamental elements that need pedagogical alternatives that favour processes of interaction and communication. In Spain, it has been pointed as mandatory to create new methodologies in the universities to give to the students a major participatory role in their own education (Ministerio de Educación y Ciencia [MEC], 2006). In this line, Lázaro (1997) has suggested that the tutorial action could be considered as a good strategy for accomplish this aim. The author has indicated that going deeper into the scientific nature of tutorial action raises major questions not only about the role played by the university in the 21 st century, but above all about the role played by university teachers in promoting a critical attitude not only in the context of the classroom.

However, as suggested by García (2008), the european countries have entered into a process of European harmonisation that generates transformations in its main agents that are inevitably linked to a new philosophy of tutorial action. In this line, as suggested by Álvarez and González (2008), in order to exercise the tutorial action, a change of conception is needed in the way in which attention and advice is guaranteed to students, always taking into account the fact that the tutorial action is also a manifestation of university teaching. As Zabalza (2013) argues, the university pedagogical role understands the university teacher less as a transmitter of knowledge and more as a person who accompanies and facilitates student learning.

\subsubsection{Experiences regarding tutorial action with university students}

In the Spanish context, research has been carried out on the impact of institutional tutorial action programmes on primary teacher education (Chiva and Ramos, 2007; López, 2013; Zabalza and Cid, 2006). In particular, Taibi (2006) carried out a tutorial action experience focused on answering specific questions, working on grammar issues, related to classes and linked to the English language. Andreu, Sanz y Serrat (2009) described a pedagogical experience in which they proposed the creation of a subject in the curriculum of a psychology faculty based on research work developed in groups. Valero, Aramburu, Baños, Sentí and Pérez (2007) described a pedagogical experience of the use of a portfolio elaborated through 
tutorial action in the continuous work of transversal competences of university students. Recently, Martínez-Bello and Martínez-Rojas (2016) have described the main characteristics of a tutorial action program developed within an academic subject in a Faculty of teacher education. The authors found that a tutorial action was an positive alternative experience in order to facilitate communication and participatory processes with university students. In other field of knowledge, Martínez (2008) analysed the reasons for using tutoring in the university environment among students of English philology. De Castro-Camero (2014) analysed the impact of a tutorial action in small groups in the framework of the elaboration of a research project in a Faculty of Law and highlights the satisfaction of the students through the cooperative work. Finally, the impact of COVID-19 on traditional tutorial action, as suggested by Seymour-Walsh, Bell, Weber and Smith (2020) may bring many course designers and educators into uncharted territory. However, to our knowledge the researchers could not locate previous studies about the impact of a tutorial action during pandemic time (in particular during the COVID-19 lockdown).

\section{Material and methods}

\subsection{Approach}

This study used a qualitative research design. At the same time, this study was an exploratory research in which open-ended, semi structured qualitative interviews and qualitative content analysis of documents were conducted. This research study was conducted from March 2020 to July 2020.

\subsection{Participants}

\subsubsection{Description of the course}

"Didactics of Physical Education in Early Childhood Education" is a compulsory course in the curriculum of teacher training in early childhood education in a Faculty of Teaching in the University of Valencia. The course was four months long and the experience was conducted between March and May 2020. During the four months, we proceeded to carry out the fulfilment of the teaching guide (University of Valencia, 2020). In order to develop a critical reflection of the role that psychomotor education play in the Early Childhood Education curriculum, the teaching guide recognize the aim to know and apply basic educational research methodologies and techniques and be able to design innovation projects identifying evaluation indicators. In order to achieve this goal the teaching guide recognize that the tutorial action programme 
should serve as a means of coordinating students in individual and group tasks, as well as evaluating individual progress, activities and teaching methodology. The model of the teacher as researcher in the classroom focuses student activity on the formulation of relevant questions, information search, analysis, elaboration and subsequent communication. The specific contents of each block will be introduced by the teaching staff and approached by the group through critical reflection. Therefore, the active and reflective participation of the students, both in the discussion generated in the classroom and in the practical activities proposed, will be fundamental in the development of the subject.

\subsubsection{Participants}

The mean age of the participants was 22 years $(S D=3.1)$. The great majority were women (98\%) while men accounted for $2 \% .90 \%$ of the participants were dedicated solely to university studies, $9 \%$ worked an average of 15 hours or more, and $1 \%$ worked less than 15 hours per week. A total of $n=40$ students participated. Before each instrument and data source performed it was explained the purpose of the actions and verbal informed consent was obtained from participant's students.

\subsubsection{Course structure}

In our university system, an academic credit ECTS (European Credit Transfer System) equates to twenty-five hours: ten for in-person activities and fifteen for independent study, tutorials, and autonomous work. The course awards six ECTS credits, delivered during semester two: Sixty hours were devoted to in-person learning (including participative classroom activities) and ninety to activities outside the classroom. The course assessment was continuous, summative, and formative, following the guidelines of the Teaching Guide. The final grade consisted of three components: $40 \%$ corresponding to theoretical and practical workshops; $30 \%$ to theoretical knowledge tests; and finally, $30 \%$ to a preliminary research project (through a tutorial action).

\subsubsection{The preliminary research Project in the tutorial action framework (before the} Pandemic)

The model of tutorial action described below is considered, following the classification of Lazaro (1997), as a combination of academic-educational tutorial developed in small groups, in which the apprehension of contents related to problematic situations is sought, becoming a 
manifestation of participatory tutoring in which interaction between the teaching staff and the small group, as well as among those who participate in the small group, is favoured, as proposed in Bologna's system of education model.

For the pedagogical design of the assignment, we selected, sequenced, and incorporated the objectives and phases suggested by Zabalza (2008) in the framework of competencybased tutorial action. To achieve that, we focused on the design of this tutorial action experience, based on teaching support, an individualized learning structure and teamwork. Because of that, developing a preliminary research project was emphasised as the foundation for the tutorial pedagogical experience. It was carried out in small groups with teaching staff support, linked to the implementation of the initial structure of research work in small groups.

At the start of the academic year, a compilation of topics linking to the relationship between the body and movement in early childhood education classrooms and other related topics was provided. Students were asked to organise in small groups of up to four members. Twelve groups of three to six students were created. They were also informed about the specific competences of the course (determined in the teaching handbook, University of, 2019-2020): "Develop a critical assessment of the role of psychomotor education in the early childhood education curriculum". After selecting the topic, creating the groups, and informing the tutor of it, the first formal tutorial was planned.

\subsubsection{Adaptation of virtual tutorials through videoconferencing (during the pandemic)}

On Saturday 14 of March 2020, the Spanish Government declared a state of emergency in the national territory, imposing social distancing to avoid the spread of COVID-19. After the consequential restrictions, the course organiser was forced to adapt the goals and contents, as well as the way the preliminary research project was conducted. The chosen method to conduct the project and tutorial action was videoconferencing. On the 25th of March 2020 students were informed of the new working protocol for the remainder of the course. Several timeslots were offered so that students learnt about the modifications and redesign of the preliminary research project in online tutorials. From the 1st of April forward, all work was conducted fully online.

The preliminary research project parts were justification, goals, research problem statement, theoretical framework, methodological design, and a reflection on the process. Students were provided with databases of interest as well as a compilation of the key international journals concerning early childhood education. Once the students selected and discussed the gathered information, the instructions for the methodological design were 
delivered. Lastly, they were suggested to develop a reflection on the creation process of the preliminary research project which was presented through videoconferencing during the three final days of the course.

\subsubsection{Virtual classroom used}

Up until in-person teaching was suspended, the University used Moodle 3.74. as a virtual classroom. When compelled to move to online teaching, complementary software was provided in addition to Moodle. Among other tools, Blackboard Collaborate was added. It is a platform that facilitates academic tasks through synchronous videoconferencing and allows the management of several pedagogical activities. Blackboard was the tool used to carry out this project's tutorials. Each team took part in between two and five synchronous videoconferences with a duration of 15 to 45 minutes.

\subsection{Instruments and data sources}

We have used four information sources to analyse the perceptions of university students on the impact of a virtual tutorial action program for developing a preliminary research project: (a) The final written documents developed by the working groups containing questions, goals and a research design proposal (b) The online oral presentation of their work, presenting and defending the creation process (c) The semi-structured interviews conducted through videoconferencing during the lockdown and, (d) The focus groups meeting two weeks after the academic year ended. Pseudonyms were used in order to protect participants' privacy. Before each instrument and data source was performed it was explained the purpose of the actions and verbal informed consent was obtained from participant's students.

\subsubsection{Questions asked in each data source}

The instruments used during the educational experience were developed ad hoc. This was due to the fact that during the COVID-19 lockdown there was not research history to rely on specific validated instruments. To this must be added the fact that we were not promoting the composition of a questionnaire for the quantification of the possible resulting data; we were interested in the most personal information, in the qualitative data obtained from the discourse of the students involved. The questions were constructed following the next procedure. Independently, the three professors participating in the educational experience formulated a series of questions that would be used in each of the information sources with the students. 
Once this was done, the professors met to share them and come up with a common set of questions that would be the final ones to be used in the data collection process.

For the final written document and oral presentations, we focused on the answers to the pre-determined questions about the experience with online tutorials. The questions were: (a) What have you learnt about the topic selected for the assignment? b) What have you learnt about research methods? (c) How did you organise the work? that is, did you interact? Have you used video conferencing? How? Which platforms have you used? (d) Identify three barriers and enablers that you perceived in conducting the preliminary research project (e) Explain to what extent the preliminary research project has been useful to you.

During the semi-structured interviews led after online tutorials, conducted during the lockdown period, we asked: (a) Had you ever attended a tutorial of this kind? How have you felt? (b) What do you think of the way the tutorial was conducted? (c) How have you organised to develop the project? (d) Have you understood the purpose of the assignment?

Lastly, the questions during the focus groups were: (a) What has isolation meant to you regarding the completion of the project? (b) Do you feel more competent, more versatile using ICTs (Information and Communication Technology) with this new work method? (c) How have you fitted this assignment with the rest of your academic workload? (d) What has the use of digital tools in your presentations entailed? (e) How do you think it has affected you, not only as students but also as future educators?

\subsection{Procedures}

A qualitative approach was used for data collection and analysis. Before each instrument and data source performed it was explained the purpose of the actions and verbal informed consent was obtained from participant's students. The audiotapes were transcribed in the traditional way, i.e. the recordings were distributed among the staff involved, who transcribed them directly into the computer. No specialised processor or programme was used for direct transcription into Word format. The transcripts and audiotapes for the oral presentations, interviews during videoconferences, and focus groups were compared and checked for accuracy. Besides, the procedure aims to compile information contrasting the results, analysing coincidences and differences in research instruments and enabling understanding in educational research (Aguilar Gaviria and Barroso Osuna, 2015). 


\subsubsection{Data analysis procedure}

The data collection and analysis was completed by using a qualitative approach. The data generated was analysed as follows. Data from the audiotapes (both interviews and focus group) were transcribed in a word document immediately after conducting the interviews. Regarding the analysis process of the other sources previously transcribed, the following procedure was used: two researchers reviewed each data source and all the transcripts independently to detect and extract meaningful quotations and reactions. For the document content analysis (the final written document and online presentation) we have followed the same previously procedure. Once the interviews and the written extracts from final document and online presentation were transcribed, we elaborated a pre-categorization of the information. Through this process, we detected the most significant issues, identifying 15 initial categories using a deductive coding scheme. Finally, multiple sources were triangulated, that is, multiple sources were used to analyse data and enhance the credibility of the research study (Fick, 2007). They were compared them and consolidated them into 7 major categories relating to the perceptions of the tutorial action trough videoconferences (Table 1). The categories on student perception took Bruner's (1963) starting point as the fact that each student constructs his or her knowledge from categories that are modified as their interaction with the environment "impacts" them. That is, the student's previous cognitive baggage will enable some connections or others with the new cognitive experiences, creating new representations of reality (Bruner, 1963). Thus, the "new reality" associated with COVID-19 led them to rethink their previous knowledge, giving rise to representations different from those expected by their environment.

\section{Results and Discussion}

Table 1 shows 7 major categories and 13 subcategories. These have been identified from the analysis of student perceptions on the impact of a virtual distance tutorial action program in developing the preliminary research project from the four information sources (final document, oral presentations, semi-structured interviews, and focus groups). 
Table 1. Initial and final codes of the qualitative analysis of university student perceptions on the impact of a virtual tutorial action program (Valencia-España,2020)

\begin{tabular}{|c|c|c|}
\hline Initial identified categories & $\begin{array}{c}\text { Source where } \\
\text { information was } \\
\text { detected }\end{array}$ & Final category \\
\hline $\begin{array}{l}\text { Identification of information } \\
\text { management competence } \\
\text { Identification of database research } \\
\text { skills } \\
\text { Lack of experience in using databases } \\
\text { as a barrier } \\
\text { Difficulty to find information related to } \\
\text { the topic }\end{array}$ & $\begin{array}{l}\text { Written document } \\
\text { Oral presentation } \\
\text { Focus groups }\end{array}$ & $\begin{array}{l}\text { Informational dimension } \\
\text { of online learning }\end{array}$ \\
\hline $\begin{array}{l}\text { Acknowledgment of an increased } \\
\text { versatility in the use of digital tools } \\
\text { Use of tools to overcome distancing } \\
\text { Enhancement in the use of previously } \\
\text { learnt and used tools } \\
\text { Slow internet connection as a barrier to } \\
\text { communication }\end{array}$ & $\begin{array}{l}\text { Written document } \\
\text { Oral presentation } \\
\text { Semi-structured } \\
\text { interviews }\end{array}$ & $\begin{array}{l}\text { The techno-utilitarian } \\
\text { dimension of online } \\
\text { learning }\end{array}$ \\
\hline $\begin{array}{l}\text { Acknowledgement of a deeper } \\
\text { knowledge on the selected topic } \\
\text { Acknowledgment of increased } \\
\text { research skills in the education field } \\
\text { Improvement in virtual content creation } \\
\text { skills }\end{array}$ & $\begin{array}{l}\text { Written document } \\
\text { Oral presentation } \\
\text { Semi-structured } \\
\text { interviews }\end{array}$ & $\begin{array}{l}\text { The cognitive dimension } \\
\text { of online learning }\end{array}$ \\
\hline $\begin{array}{l}\text { Acknowledgement of the importance of } \\
\text { cooperative online work for } \\
\text { competence development } \\
\text { Lack of in-person contact among group } \\
\text { members as a barrier } \\
\text { Acknowledgment of the barriers of } \\
\text { online dialogue } \\
\text { Virtual meetings as a social opportunity } \\
\text { during lockdown } \\
\text { The trust and harmony of the group as } \\
\text { enablers of the online group work }\end{array}$ & $\begin{array}{l}\text { Written document } \\
\text { Oral presentation } \\
\text { Semi-structured } \\
\text { interviews } \\
\text { Focus groups }\end{array}$ & $\begin{array}{l}\text { The social dimension of } \\
\text { online learning }\end{array}$ \\
\hline $\begin{array}{l}\text { New cooperative working methods } \\
\text { online } \\
\text { Development of autonomy enhanced } \\
\text { by online environments } \\
\text { Increased interdependence among } \\
\text { group members } \\
\text { Organisation of the preliminary } \\
\text { research project simultaneously with } \\
\text { other assignments } \\
\text { Great autonomous workload in other } \\
\text { subjects } \\
\text { Personal and family issues as a barrier }\end{array}$ & $\begin{array}{l}\text { Semi-structured } \\
\text { interviews } \\
\text { Focus groups }\end{array}$ & $\begin{array}{l}\text { The organisational } \\
\text { dimension of an online } \\
\text { learning environment }\end{array}$ \\
\hline
\end{tabular}




\begin{tabular}{|c|c|c|}
\hline $\begin{array}{l}\text { Freedom in selecting a topic } \\
\text { The importance of topic selection as a } \\
\text { motivational element } \\
\text { Personal interest to learn about the } \\
\text { chosen topic }\end{array}$ & $\begin{array}{l}\text { Semi-structured } \\
\text { interviews } \\
\text { Focus groups }\end{array}$ & $\begin{array}{l}\text { The essential role of } \\
\text { intrinsic motivation to } \\
\text { overcome perceived } \\
\text { barriers }\end{array}$ \\
\hline $\begin{array}{l}\text { Self-awareness on strengths and } \\
\text { weaknesses regarding the use of ICTs } \\
\text { The identification of elements to } \\
\text { improve in the future professional } \\
\text { career }\end{array}$ & Focus groups & $\begin{array}{l}\text { The critical reflection on } \\
\text { the impact of virtual and } \\
\text { distanced education in } \\
\text { the early childhood } \\
\text { education curriculum }\end{array}$ \\
\hline
\end{tabular}

The reflection in the use of ICT in the creation of audio-visual content

Source: Prepared by the authors based on the information from the four information sources, 2020 .

\subsection{The informational dimension of online learning}

The first category identified from the data source analysis is linked to the opportunity of students to improve their research and data management skills. In this vein, Lobato, Arbizu and del Castillo (2004) suggest that educators consider their main task to be the accompaniment in skills acquisition inside and outside the university. Students participating in this ICT-led preliminary research process manifest that the assignment allowed them access to scientific articles related to their selected topics:

"Library and online data bases" (Oral presentation, group 2).

"Ubiquity and ease of access to data sources" (Oral presentation, group 5).

In this regard, students have been observed to acknowledge a direct link between the versatility in data research and the self-perception of skills linked to the subject and their degree. Two students point out:

"I was quite used to going to the library... researching through databases, citing online articles, to be fair, it has been complicated... yes, I feel more competent now that I have used those" (Student 1, focus group I).

However, despite the ease of access to databases and scientific articles in their field, some groups have identified barriers to their learning process. For instance, some groups remark the following about oral presentations:

"Difficulty to find articles and documentation about the research topic" (Oral presentation, group 2). 
"Lack of information about the topic of early childhood education" (Oral presentation, group 12).

\subsection{The techno-utilitarian dimension of online learning}

As stated before, students feel competent to use databases. They are also comfortable with using synchronous communication software such as Skype, Zoom, and Hangouts. Those tools and online services available and used by students are considered enablers for most groups:

"In order to support and enhance the quality of our work, we have used, synchronously, the digital platform Skype..." (Written document, group 12).

"We used Skype to communicate, debate and solve doubts" (Written document, group 9).

In the same vein, Al-Emran, Elsherif, and Shaalan (2016) analysed students' attitudes towards mobile technology. They found an overall positive perception of the usefulness of mobile devices. Concretely how they facilitate information and material access, retrieval, and exchange, and allow their self-improvement and the development of skills and learning. Although in general terms the use of technological instruments guaranteed the interaction and communication among group participants, other students identified inconveniences about the difficulty of moving online derived from the digital gap. A group states:

"Very often our work has been affected by the poor connection we had from home" (Written document, group 10).

Those statements confirm how educational inequality (of a different sort) can be enhanced because of the digitalisation of learning and teaching processes (Jiménez, 2020) and technical constraints (Nguyen et al.,2020). Agarwal and Kaushik (2020) found that students identified technical faults during sessions as barriers to the teaching process. We agree with Toquero (2020) and Díaz, Molina and Monfort (2019), in stating that university as an institution must train students and staff in digital skills to respond to structural challenges, such as the move to hybrid learning and conjunctural issues like COVID-19. 


\subsection{The cognitive dimension of online learning}

Lobato et al. (2004) suggest that students' ignorance of the formative possibilities that tutorial action offers leads their participation interest to be short-sighted disregarding the longterm potential. Sanz (2012) showcases the convenience of informing students of the potential of tutorials, to maximize the utility of those spaces and the quality of higher education. Concerning that, we have observed that students perceive the importance of the study of research methods to access the final dissertation:

"The development of this project brought us closer to the research world... which encouraged us to do research ourselves when we become teachers" (Written document, group 4).

Recently, Ng and Peggy (2020) training suggested a 3-step virtual classroom approach: plan appropriate tasks; select essential resources and perform effective delivery. Moreover, in the field of virtual interaction Seymour-Walsh et al. (2020) suggested that course designers should clearly identify the core learning objectives to promote an interactive environment to support communities of inquiry in online tutorials. A group pointed out:

"It allowed us to share our experiences [...] which was beneficial in gaining a critical perspective" (Written document, group 6).

This critical thinking that must be encouraged in the formation of early childhood education teachers, promoting dialogic teaching perspectives, has not lost its relevance. Rogero-García's (2020) prediction of a negative impact of the heath alarm, by reducing the relevance of learning processes based on discussion and debate, has not come true. Instead, future educators have acknowledged that learning in the classroom is also about researching (Feito, 2020).

Students recognise the scarcity of research conducted in our mother tongue in the context of early childhood education. However, the barrier is not as much related to the procedures developed as a response to COVID-19 but more to the academic and linguistic requirements of the university. Some students state the following:

"Lack of information about eating disorders during childhood" (Written document, group 8).

"Scarcity of documents, research and articles focusing on our specific research topic" (Written document, group 4). 
Finally, it must be kept in mind that this process has aimed to make students autonomous knowledge-builders allowing them to take responsibility for their learning in the short, medium, and long term. About that, Anderson (1997) maintains that the perception of university students of academic tutorial action focuses mostly on improving the construction of knowledge and on the quality of their own discussions and conclusions. It must be highlighted that the presented proposals were diverse, with a variety of thoughts, procedures, needs, and interests to complement their development as early childhood educators. Examples of those are:

"What is the impact of children's advertising on how they perceive their own image and others'?".

"How do natural habitats influence psychomotricity in early childhood education?".

"How do psychomotor practices influence the development of a body scheme considering their drawings?" (Research questions developed by groups).

\subsection{Social dimension of online learning}

In addition to the instrumental and cognitive impact of the preliminary research project, we have observed the social impact of the new work dynamics through online cooperative learning environments. Students have identified new methods of cooperation through creating and sharing of knowledge in digital settings. For instance, through synchronous tools such as Skype or Zoom, they debated and shared ideas, through WhatsApp they communicated and with Google Drive the created notes and curricular materials cooperatively. Students consider educational technology an enabler for communication and interaction, which, for Casey, Goodyear and Armour (2016) are required mediators for online learning. Groups say:

"It made us realise that we can actually work as a group virtually. Now we are more openminded towards this work method which removes the distance barrier" (Written document, group 8).

In the same line, Huang et al. (2020) have identified that using cooperative and social learning tools for online education in emergencies is beneficial to learners in finding and processing information, constructing knowledge, collaborating with peers, expressing understanding, and evaluating learning impacts. A group reflection confirms it:

"All the group members have worked together and cooperatively, trying to complement our knowledge and skills and resolving concerns as a team" (Written document, group 10). 
In this sense, we have encountered that the use of ICT, especially for virtual interaction, has been a positive experience during hard times. For instance, a student says:

"I believe the lockdown itself and ICTs have allowed us to be face to face, it really felt as

if we were all together" (student 3 , focus group II).

About that, Al-Emran et al. (2016) found that perception of mobile technology's role in supporting communication with colleagues and instructors emerged as an important element of distance learning. In this regard, Nguyen et al. (2020) have suggested that digital formats could potentially allow the required social distancing during the pandemic. Likewise, Agarwal and Shankar (2020) found that how students lived and experienced the online teaching sessions during the COVID-19 pandemic revealed the impact of this kind of online learning on their morale by creating a diversion from the ongoing situation. Furthermore, Gallagher and Schleyer (2020) found that students and trainees experienced a considerable loss of social connections during the COVID-19 pandemic. In fact, we agree with Huang et al. (2020) that online instructional practice should involve using online communication, ensuring regular human interactions, and addressing potential online challenges, such as learners' perceived loneliness or helplessness.

At the same time, the analysis of videoconference tutorials points out to the pre-existing friendship among group members as an enabler for the development of the preliminary research project. Students say:

"We are a group where we have confidence in each other when presenting ideas, and that makes our work easier" (Semi-structured interview, group 12).

A key aspect of the new paradigm of higher education is centring the learning processes around the interaction among the participating subjects (Lobato et al.,2004; Sola \& Moreno, 2005) where educators lose their central role and become enablers of students' autonomous knowledge management. Moreover, as suggested by Seymour-Walsh, Weber and Bell (2020), students must have opportunities to interact with the tutor and each other, to co-construct professionally relevant meaning with their peers. In fact, for some students, the key benefit of tutorials is the ability to communicate with participants to answer questions, regardless of the channel used. A student brings up: 
"I think there is no problem, I mean, as long as we can do tutorials and we get answers to out questions, it is the same as going to the office to ask something" (Semi-structured interview, group 8).

All of the former combined, we consider the way academic support is provided through digital environments during the social distancing situation can positively condition not only the educational experience but also the personal and social experience caused by the absence of personal contact among the members of the educational community.

\subsection{The organisational dimension of an online learning environment}

Zhang et al. (2020) point out that students and teachers have trouble when studying and teaching at home. However, in this case, groups found the negotiating mechanisms through which they managed to develop this project along with other subject's assignments. In fact, when analysing the videoconferences, students appear to identify organisation and time management as a key factor to succeed. Some groups stated:

"We kind of planned how many days we have and how many we will use for work this week and what we want to get done no matter what" (Student 1, focus group II).

In this framework, we observed how the new work dynamics focused on interaction and support throughout the project were aimed at reducing those personal and communicative barriers. Students acknowledged that inter-student relationships and teaching support in learning confirm the importance of institutional and emotional advice; which have been a key task for educators during the online learning period (Villafuerte, Bello, Pantaleón and Bermello, 2020). This is backed by statements such as:

"The existing comradeship among group members" (Written document, group 11).

"The good academic and personal communication we had" (Written document, group 8).

Regarding the involvement of the educator, this model is incompatible with a traditional teaching role. Students recognise the implication and flexibility of the teacher as an enabler for the process. Students say:

"I think as well that having tutorials through videoconference is convenient ..." (Semistructured interview, working group 7). 
"The teacher's availability has been of great help... the quick replies to answer our questions and to meet us virtually to discuss mistakes and improvements..." (Written document, group 8).

However, this atmosphere of trust and proximity among group members is only possible if they can find alternatives to cooperative work in the framework of online working. In fact, students point out:

"We have been all three, all doing all the questions... we want to do it together because, for example, I don't know what part my classmate did but, we end up doing it all at the same time" (Semi-structured interview, group 12).

\subsection{The fundamental role of intrinsic motivation to overcome the perceived barriers}

Anderson (1997) points out that if the student perceives the tutorial action is not oriented to a specific set of tasks, the discussions between teachers and small groups will be of poor quality. In this regard, intending to develop research methodology skills, the analysis of focus groups conducted after the course completion, yields an important fact: the intrinsic motivation generated by the task was essential to successfully develop the preliminary research project. As two students say:

"I was motivated, I enjoyed doing it and then, if I had to prioritise something, it was this task, not the others, I was looking forward to doing it" (student 2, focus group II).

"And it also generated this motivation, and that is why we enjoyed the theoretical aspect... but also the practical side of asking ourselves, hey, let's see how many people think this way..." (student 3 , focus group II).

In the same line, Agarwal and Shankar (2020) found that during the pandemic, medical students felt motivated to read on the topics they were learning about, as it helped them not to think of COVID-19 and sleep peacefully. Several learners lack crucial learning competencies, such as self-regulation and motivation, which are key factors for successful online learning (Huang et al. 2020). To reduce that lack of self-drive, Martínez-Navarro (2017) pinpoints how technological resources can act as motivational tools through, for example, gamification, which encourages participation and can improve the results of the learning process. Therefore, giving meaning to the process of tutorial action in the framework of distance learning as well, will 
encourage student adherence, which proves positive in the long term, as will be observed in detail below.

\subsection{The critical reflection on the impact of virtual and distanced education in the early childhood education curriculum}

We also wanted to analyse the impact of carrying out the project in their future teaching, when embedding digital tools and services. From the answers, we constructed three subcategories. The first one, aims to know the status of early childhood education in the postCOVID-19 era. About that, students explain:

"I consider it good in the sense of creating content for my future classroom, but I don't like it for class, I would rather work closely and with natural methods... but to create content, it is good" (student 1 , focus group II).

“The ability to do online tutorials with children, but I don't know, I would rather have inperson contact... I think direct communication will be of a higher level" (Student 3, focus group II).

The second one, springs from the analysis of the final written documents. We detected that academic work-life balance is a perceived barrier for some. A group points out:

"... it is hard to simultaneously deal with family situations and university work, as the workload was high and family situation were really different" (Written document group 1).

However, time management was a key factor to adapt to the spontaneous situation generated by the pandemic. In fact, that led us to centre the discussion in the focus group around the perceived barriers students would not like to see in their future classrooms. For example, a student expressed:

"For me, this is a way to pay attention to the things I was missing as a student and learn what children need so that the same does not happen to them... for example miscommunication and lack of engagement" (Student 1, focus group I).

In fact, Baloran (2020) found that most university students during the COVID-19 pandemic in Southern Philippines displayed anxiety during the lockdown period. Therefore, we agree with Zhang et al. (2020) when suggesting that the findings of these investigations will enable schools to provide targeted instruction and counselling service for students with learning 
difficulties during the pandemic, and support students' successful re-adaptation to online school education after the pandemic.

The third one, focuses on identifying alternatives to make the use of technology in distance education more attractive, especially in the framework of audio-visual content creation. Sáez and Ruiz (2014) point out how videoconferences can motivate students and promote critical learning. A student explains:

"It is essential to know the children... we can start to complement education with audiovisuals and recordings, which generate interest" (Student 1, focus group II).

Finally, students consider the preliminary research project, conducted through online tutorials, allowed them to broaden their field of study and possibilities as teachers and researchers.

\subsection{Limitations of the preliminary research project}

Students identify room for improvement in some aspects of the online preliminary research project. Two students point out:

"Maybe if it were possible to upload all the videos to watch at home and really understand... downloading maybe, for me it would be much more enriching and I would learn much more" (Student 2, focus group II).

"I still miss the thrill of fear before a presentation... I like to the see body language of those who are explaining something..." (Student 2, focus group I).

\section{Limitations of the university experience}

This work has limitations that can be improved in future experiences. Firstly, the results of our educational experience are merely descriptive, which is why no cause-effect relationships can be drawn from them. However, future educational experiences and research could improve this aspect. Secondly, it would be interesting to analyse the perception of teachers during a tutorial actions well on site or online. Thirdly, the novelty of carrying out interaction and communication processes that both students and teachers had never faced before. Fourth, the need to facilitate a better understanding of the phenomena to be analysed, i.e. the need to articulate the importance of educational research in the training of future Early Childhood Education teachers from the beginning of their studies. Finally, the need to broaden participants' knowledge of the use of distance communication tools. It is important to remember that the educational experience was carried out during the most difficult months of confinement 
in our country. That is to say, the academic results as a result of interaction via videoconference with the students were achieved during a difficult psychological, economic and health situation. To our knowledge, no qualitative university experiences have been shared on what it meant for the students to continue their university education during the lockdown months. In any case, it is considered that the results of the experience as well as the information collected are robust and fill a very large conceptual gap on the role of tutorial action in the training of future Early Childhood Education teachers during a new time that generates new challenges for the whole educational community.

\section{Further research}

Taking into account that use of ICTs during the COVID era has proved to be a trend accelerator, it is possible an irreversible move of higher education to hybrid models. To implement those models, higher education teachers will need an ethical, critical and emancipatory digital competence (Casey et al., 2016; Díaz, 2020), that guarantees equity, privacy and security and avoids digital gaps (Díaz et al., 2019). This alternative technopedagogical model will also need to fight the dystopic and techno-phobic positions emerging as a reaction to the rise of Artificial Intelligence (Big Data, Machine Learning, Learning Analytics, etc.) and educational robotics.

Finally, further studies should take into account that security, privacy, and data protection are related to with pedagogical practice. For instance, university students recognize the use of non-institutional tools like WhatsApp in their learning. They have also used Zoom, a software that, according to the National Institute of Cybersecurity (INCIBE, 2020) is vulnerable because of its inability to protect personal data or prevent fraud and cyberattacks. The low awareness of their vulnerability, the inexperience in preserving data privacy or the ignorance of basic juridical aspects among university students may be due to, according to Díaz (2020), their limited training in digital competence, magnified by the health emergency scenario that compelled a sudden move from a traditional to a virtual system.

\section{Conclusions}

To our knowledge, no experience has been carried out, assessed and disseminated that describes the whole process of tutorial action in small groups during the COVID-19 lockdown. It is considered that the process of tutorial action as an alternative experience in our University 
will help to clarify pedagogical mechanisms to promote communicative and participatory processes in university education that are more in tune with a student-centred education.

Throughout this work we have presented a first approach to one of the great challenges of the new role of university teaching staff in times in which on-site teaching shares processes and actions with off-site teaching, as well as the need to implement interaction and communication processes to favour the continuous work of transversal and specific competences of university students. This experience aims to show itself as an alternative in times of social distancing to carry out accompaniment processes with students. Finally, this experience does not claim to be the only option. Each professor will have to create his or her own way of adapting to this new scenario. However, it is considered that it can be an option to be reviewed, improved and completed in university classrooms by those professor who consider it convenient to change education towards a paradigm of student-centred teaching. Thus, new questions arise about the process of implementing tutorial action in the university classroom.

Our results have highlighted the barriers and facilitators perceived by university students during the implementation of a tutorial action program aiming to develop a preliminary research project in a Faculty of Teaching during the COVID-19 pandemic. Following the results of our study we can point out that: (a) students find videoconferences are a tool that offsets the issues of social distancing; (b) intrinsic motivation is essential to overcome the perceived barriers to conducting the preliminary research project; (c) the move to a virtual environment allowed students to deepen their methodological skills for future projects; (d) students now see themselves as more competent and versatile regarding academic information research and use; e) the constant interaction and communication among group members and the teacher is a key element to achieve a positive educational experience during social isolation; (f) new logistic and operational dynamics for cooperative working were constructed as a result of using videoconferences; g) students are now more aware of the challenges of virtual education in their future career development and in early childhood education. From these findings, we concluded that higher education institutions and teachers can and must consider new alternatives for students to develop their professional skills.

\section{References}

Agarwal, Sakshi., and Shankar Kaushik, Jaya. (2020). Student's perception of online learning during COVID pandemic. Indian Journal of Pediatrics, 87(7), 554. doi: https://doi.org/10.1007/s12098-020-03327-7 
Aguilar Gavira, Sonia., y Barroso Osuna, Julio Manuel. (2015). La triangulación de datos como estrategia en investigación educativa. [Data triangulation as a strategy in educational research]. Píxel-Bit. Revista de Medios y Educación, (47), 73-88. Doi: http://dx.doi.org/10.12795/pixelbit.2015.i47.05

Al-Emran, Mostafa., Elsherif, Hatem., y Shaalan, Khaled. (2016). Investigating attitudes towards the use of mobile learning in higher education. Computers in Human behavior, 56, 93-102. Doi https://doi.org/10.1016/j.chb.2015.11.033

Almazán, Adrián. (2020). Covid-19: ¿Punto Sin Retorno de la Digitalización de la Educación? [Point of No Return on Digitization of Education]. Revista Internacional de Educación para la Justicia Social, 9(3e), 1-4. Recovered from https://revistas.uam.es/riejs/article/view/12089

Álvarez, Pedro Ricardo., y González, Mirian Catalina (2008). Análisis y valoración conceptual sobre las modalidades de tutoría universitaria en el espacio europeo de educación superior. Revista Interuniversitaria de Formación del Profesorado, 22(1), 49-70.

Anderson, Charles. (1997). Enabling and shaping understanding through tutorials. En Ference Marton, Dai Hounsell y Noel Entwistle (Eds.), The experience of learning (2nd ed.; pp. 184-197). Edinburgh: Scottish Academic Press.

Andreu Barrachina, Llorenç., Sanz Torrent, Mónica., y Serrat Sellabona, Elisabet. (2009). Una propuesta de renovación metodológica en el marco del espacio europeo de enseñanza superior: Los pequeños grupos de investigación cooperativos. Revista electrónica interuniversitaria de formación del profesorado, 12(3), 111-126. Recovered from https://www.redalyc.org/articulo.oa?id=217015345009

Baloran, Erick. (2020). Knowledge, Attitudes, Anxiety, and Coping Strategies of Students during COVID-19 Pandemic. Journal of Loss and Trauma, 25(8), 635-642. Doi https://doi.org/10.1080/15325024.2020.1769300

Beltrán, José., Venegas, Mar., Villar-Aguilés, Alicia., Andrés-Cabello, Sergio., Jareño-Ruiz, Diana., y De Gracia-Soriano, Pablo. (2020). Educar en época de confinamiento: La tarea de renovar un mundo común. [Educating in Times of Confinement: The Task of Renewing a Common World]. Revista de Sociología de la Educación, 13(2), 92-104.

Bruner, Jerome. (1963). El proceso de la educación. México: UTEHA.

Casey, Ashley., Goodyear, Victoria., y Armour, Kathleen. (2016). Rethinking the relationship between pedagogy, technology and learning in health and physical education. Sport, $\begin{array}{lllll}\text { Education } \quad \text { Society, } & \text { 22(2), } & \text { Doi }\end{array}$ https://doi.org/10.1080/13573322.2016.1226792

Chick, Robert Connor., Clifton, Guy Travis., Peace, Kaitlin., Propper, Brandon., Hale, Diane., Alseidi, Adnan., y Vreeland, Timothy. (2020). Using technology to maintain the education of residents during the COVID-19 pandemic. Journal of Surgical Education, 77(4), 729-732. Doi https://doi.org/10.1016/j.jsurg.2020.03.018 
Chiva, Inmaculada., y Ramos, Genoveva. (2007). Una reflexión acerca de las tutorías universitarias a partir de las valoraciones realizadas por Profesores Tutores de la Universitat de València. REOP-Revista Española de Orientación y Psicopedagogía, 18(2), 179-187. Doi: https://doi.org/10.5944/reop.vol.18.num.2.2007.11310

De Castro-Camero, Rosario. (2014). La tutoría en pequeños grupos como recurso formativo para el aprendizaje del Derecho Romano. REDU. Revista de Docencia Universitaria, 12(3, extraordinario), 269-292. https://doi.org/10.4995/redu.2014.5503

Díaz, José. (2020). Challenges and opportunities of mobile technology in physical education. Retos: nuevas tendencias en educación física, deporte y recreación, 37, 763-773.

Díaz, José., Molina, Javier., y Monfort, Manuel. (2019). Primary Physical Education teachers' attitudes and interests towards ICT in the Valencian Community. Retos: nuevas tendencias en educación física, deporte y recreación, (35), 267-272. Doi http://dx.doi.org/10.47197/retos.v0i35.63355

Feito, Rafael. (2020). Este es el fin de la escuela tal y como la conocemos. Unas reflexiones en tiempo de confinamiento. Revista de Sociología de la Educación, 13(2), 156-163. Doi https://ojs.uv.es/index.php/RASE/article/view/17130

Flick, Uwe. (2007). Methodological triangulation in Qualitative research. In Uwe Flick (Ed.), Managing Quality in Qualitative Research (pp. 54-74). London: SAGE.

Gallagher, Thomas., and Schleyer, Anneliese (2020). "We Signed Up for This!"-student and trainee responses to the COVID-19 pandemic. New England Journal of Medicine, 382, e96. DOI: 10.1056/NEJMp2005234

García, Narciso. (2008). La función tutorial de la universidad en el actual contexto de la educación superior. Revista Interuniversitaria de Formación del Profesorado, 22(1), 21 48. Recovered from file:///C:/Users/Rebeca/AppData/Local/Temp/DialnetLaFuncionTutorialDeLaUniversidadEnEIActualContexto-2541038.pdf

González-Zamar, Mariana-Daniela., Abad-Segura, Emilio., y Bernal-Bravo, César (2020). COVID-19 y espacios de aprendizaje universitarios. Tendencias en investigación. IJERI: International Journal of Educational Research and Innovation, (15), 82-100. Recovered from https://dialnet.unirioja.es/servlet/articulo?codigo $=7517814$

Guadix, Sergio., Winston, Graham., Chae, John., Haghdel, Arsalan., Chen, Justin., Younus, lyan., Radwanski, Ryan., Greenfield, Jeffrey., y Pannullo, Susan. (2020). Medical student concerns relating to neurosurgery education during COVID-19. World Neurosurgery, 139, e836-e847. doi https://doi.org/10.1016/j.wneu.2020.05.090

Huang, Ronghua.i, Liu, Dejian., Tlili, Ahmed., Yang, Junfeng., Wang, Huanhuan., Gao, Bojun., Lu, Hang., Chang, Ting-Wen., Cheng, Qian., Yin, Xiayu., y Cheng, Wei. (2020). Handbook on Facilitating Flexible Learning During Educational Disruption: The Chinese Experience in Maintaining Undisrupted Learning in COVID-19 Outbreak. Beijing: Smart Learning Institute of Beijing Normal University. 
Instituto Nacional de Ciberseguridad (INCIBE). (2020). Vulnerabilidad descubierta en el sistema de videoconferencia Zoom. Recovered from https://www.incibe.es/protege-tuempresa/avisos-seguridad/vulnerabilidad-descubierta-el-sistema-videoconferencia$\underline{z o o m}$

Jiménez, Juan Carlos. (2020). Polémicas Educativas en Confinamiento. [Educational Controversies in Confinement]. Revista Internacional de Educación para la Justicia Social, 9(3e), 1-5. Recovered from https://revistas.uam.es/riejs/article/view/12084/12006

Lázaro, Ángel. (1997). La acción tutorial de la función docente universitaria. [The tutorial action of the university teaching function]. Revista complutense de educación, 8(1), 233-252. Recovered from https://dialnet.unirioja.es/servlet/articulo?codigo=150210

Lobato, Clemente., Arbizu, Felisa., y del Castillo, Laura. (2004). Las representaciones de la tutoría universitaria en profesores y estudiantes: estudio de un caso. Educación XX1, (7), 135-168. Recovered from https://www.redalyc.org/pdf/706/70600707.pdf

López, Ernesto (2013). La tutoría en la universidad: Una experiencia innovadora en el grado de educación primaria. REDU. Revista de Docencia Universitaria, 11(2), 243-261. DOI: https://doi.org/10.4995/redu.2013.5575

Martínez, María. (2008). Explorando las tutorías en el proceso de convergencia europea. Revista de Enseñanza Universitaria, (32), 29-36. Recovered from http://rua.ua.es/dspace/bitstream/10045/17346/1/REU2008Tutorias.pdf

Martínez-Bello, Vladimir Essau., y Martínez-Rojas, Ángela. (2016). La acción tutorial académica en pequeños grupos: Una experiencia educativa con estudiantes universitarios. Revista Electrónica Educare, 20(2), 438-463. doi: http://dx.doi.org/10.15359/ree.20-2.21

Martínez-Navarro, Gema. (2017). Tecnologías y nuevas tendencias en educación: aprender jugando. El caso de Kahoot. Opción: Revista de Ciencias Humanas y Sociales, 33(83), 252-277. Recovered from https://www.redalyc.org/articulo.oa?id=31053772009

Ministerio de Educación y Ciencia. (MEC). (2006). Propuestas para la renovación de las metodologías educativas en la Universidad. Madrid: Secretaría General Técnica.

Ng, Yuet-Ming., y Peggy, Pui Lai. (2020). Coronavirus disease (COVID-19) prevention: Virtual classroom education for hand hygiene. Nurse Education in Practice, 45, 102782. Doi https://doi.org/10.1016/i.nepr.2020.102782

Nguyen, Khang., Enos, Tyler., Vandergriff, Travis., Vasquez, Rebecca., Cruz, Ponciano., Jacobe, Heidi., y Mauskar, Melissa. (2020). Opportunities for education during the COVID-19 pandemic. JAAD International, 1(1), 21-2. doi: 10.1016/i.jdin.2020.04.003

Plancher, Kevin., Shanmugam, Prasad, Jaya., y Petterson, Stephanie. (2020). The Changing Face of Orthopedic Education: Searching for the New Reality After COVID-19. Arthroscopy, Sports Medicine, and Rehabilitation, 2(4), e295-e298. doi: https://doi.org/10.1016/j.asmr.2020.04.007 
Rogero-García, Jesús (2020). La ficción de educar a distancia [The fiction of distance education]. Revista de Sociología de la Educación, 13(2), 174-182. doi: https://doi.org/10.7203/RASE.13.2.17126

Saez-López, José Manuel y Ruiz-Gallardo, José-Reyes. (2014). La Enseñanza De Las Ciencias Naturales Y Sociales a Través De La Videoconferencia Interactiva. Estudio De Caso En Educación Primaria (Teaching Natural and Social Sciences through Interactive Video Conferencing. Case Study in Elementary Education.). Píxel-Bit, Revista de medios y educación, (44), 35-49.

Sánchez, Melchor., Martínez, Ana María del Pilar., Torres, Ruth., de Agüero, Mercedes., Hernández, Alan., Benavides, Mario., Rendón, Víctor., y Jaimes, Carlos. (2020). Retos educativos durante la pandemia de COVID-19: una encuesta a profesores de la UNAM. [Educational challenges during the COVID-19 pandemic: a survey of UNAM teachers]. Revista Digital Universitaria, 21(3), $1-24 . \quad$ Doi: http://doi.org/10.22201/codeic.16076079e.2020.v21n3.a12

Sanz Díaz, María Teresa. (2012). Estudio de la acción tutorial como paso previo a la implantación del EEES en la licenciatura de Administración y Dirección de Empresas de la Universidad de Huelva. [Study of the tutorial action as a previous step to the implementation of the EHEA in the degree of Business Administration and Management at the University of Huelva]. Revista de Investigación Educativa, 30(1), 145-160. Recovered from https://dialnet.unirioja.es/servlet/articulo?codigo=3837225

Seymour-Walsh, Amy., Bell, Andy., Weber, Anthony., y Smith, Tony. (2020). Adapting to a new reality: COVID-19 coronavirus and online education in the health professions. Rural and Remote Health, 20(2), 6000. DOI: 10.22605/RRH6000

Sola, Tomás., y Moreno, Antonio. (2005). La acción tutorial en el contexto del espacio europeo de educación superior. Educación y Educadores, 8, 123-144. Recovered from https://www.redalyc.org/pdf/834/83400810.pdf

Taibi, Mustapha (2008). Reconsidering tutorials and student-lecturer power relationships in language subjects. Porta Linguarum, (6), 23-32. Recovered from http://www.ugr.es/ portalin/articulos/PL numero6/taibi.pdf

Toquero, Cathy Mae (2020). Challenges and Opportunities for Higher Education amid the COVID-19 Pandemic: The Philippine Context. Pedagogical Research, 5(4), em0063. Doi https://doi.org/10.29333/pr/7947

University of Valencia. (2020). Teaching guide Didactis of Physical Education in Early Childhood Education. University of Valencia. Recovered from https://www.uv.es/fatwirepub/Satellite/universitat/es/asignaturas1285846094474.html?idA=33622\&idT=1304;2020

Valero, Mireia., Aramburu, José., Baños, Josep-Eladi., Sentí, Mariano., y Pérez, Jorge. (2007). Introducción de un portafolio para fomentar competencias transversales de los estudiantes universitarios. Educación Médica, 10(4), 244-251. Recovered from http://scielo.isciii.es/scielo.php?script=sci arttext\&pid=S1575-18132007000500008 
Villafuerte, Jhonny., Bello, Johanna Alexandra., Pantaleón, Yisela., y Bermello, Jinsop Omar (2020). Rol de los docentes ante la crisis del COVID-19, una mirada desde el enfoque humano. [The role of teachers in the COVID-19 crisis, a view from a human perspective]. Revista Electrónica Formación y Calidad Educativa, 8(1), 134-150. Recovered from http://www.refcale.uleam.edu.ec/index.php/refcale/article/view/3214

World Health Organization. (2020, March 18). Mental health and psychosocial considerations during the COVID-19 outbreak. Recovered from https://www.who.int/docs/defaultsource/coronaviruse/mental-health-considerations.pdf

Zabalza, Miguel Ángel. (2008). El trabajo por competencias en la enseñanza universitaria. En Imelda Rodríguez Escanciano (Ed.), El nuevo perfil del profesor universitario en el EEES: claves para la renovación metodológica (pp. 79-113). Madrid: Universidad Europea Miguel de Cervantes, Servicio de Publicaciones.

Zabalza, Miguel Angel. (2013). Ser docente es más que ser enseñante. REDU. Revista de Docencia Universitaria, 11(2), 11-13. DOI: https://doi.org/10.4995/redu.2013.5563

Zabalza, Miguel Angel., y Cid, Alfonso. (2006). La tutoría en la universidad desde el punto de vista del profesorado. Bordón. Revista de Pedagogía, 58(2), 247-268. Recovered from https://recyt.fecyt.es/index.php/BORDON/article/view/39618

Zhang, Wunong., Wang, Yuxin., Yang, Lili., y Wang, Chuanyi. (2020). Suspending Classes Without Stopping Learning: China's Education Emergency Management Policy in the COVID-19 Outbreak. Journal of Risk and Financial Management, 13(3), 1-6. 
Revista indizada en

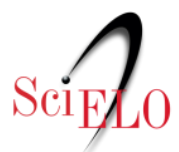
redalyc sy latindex

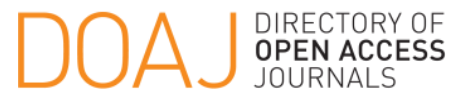

Distribuida en las bases de datos:

- Dialnet

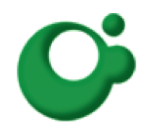
SHERPA/RoMEO

REDIB

$\underset{\substack{\text { Red Iberoamericana } \\ \text { de Innovación y Conocimiento Cléntfico }}}{\text { Red }}$

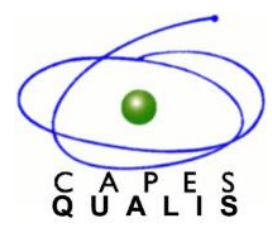

MIAR 